\title{
The Concept of Peace in the Pentateuch
}

\author{
Uri Zur
}

Ariel University, Ariel, Israel

\begin{abstract}
Peace is a key concept in Jewish tradition with an extensive history. It is also an extremely broad concept. As former deputy to the president of Israel's Supreme Court, Chief Justice Prof. M. Elon, stated at a lecture he delivered at a 2004 conference at Haifa University, that peace is equivalent to liberty, justice, and equity. The purpose of this chapter is to discuss various attitudes and ideals concerning peace that are reflected in a selection of sources from the Hebrew Bible and are complemented by other Jewish sources.
\end{abstract}

Keywords: peace, Judaism, Pentateuch

\section{Introduction}

The concept of peace in early Jewish sources will be defined on three levels. The first level encompasses the relationship of peace to God, man's relation to God, and God's relation to man, and the divine blessing of peace from God to man. Next, the author discusses peace as a condition of an individual's state and a feature of an individual's relationships with others, including relationships with their spouses and their environment. The author also discusses biblical Moses and Aaron, as exemplars of peace. Finally, the author examines the concepts of peace and war between nations, and the potential conflict between peace and truth.

Today, while opinions in Judaism are divided on many issues, all streams within the Jewish tradition believe in the concept of peace although each stream supports a concept of peace that is subject to different limitations or reservations.

\section{The Jewish Concepts of Peace}

In Judaism, the concept of peace encompasses three main elements: First is the lexical meaning of the word "peace" which is a description of a condition - tranquility, serenity, quiet, a condition that is opposite to the state of war; its second meaning stems from the linguistic inflections of the Hebrew root of the word: "Shalom" and denotes completion, perfection, and reward (Schwartz, 1997, pp. 7-11); and the third meaning of peace, which is based on Abarbanel's commentary, is harmony.

Don Yitzhak Abarbanel, a biblical philosopher and commentator who lived in 15th century Portugal, interpreted the word "peace" as peace pertaining to the common good. "True peace between opposing forces which [God] created in his world" (Abarbanel, 2013, p. 49). According to this interpretation, peace implies harmony (Schwartz, 1997, p. 15) and a reconciliation of different things, people or opinions with each element making its own unique contribution to the completeness of the whole. Schwartz (1997) describes his approach to

Uri Zur, Ph.D., Israel Heritage Department, Ariel University. 
peace as follows: "Peace in an individual's life is the state of harmony and serenity, goodness and tranquility, fecundity of the land and seed, physical health, and longevity” (p. 15).

\section{Peace Pertaining to God and God's Attitude Towards Man}

The concept of peace is also used to describe God's actions, and is reflected in several of the many names of God. Shalom is one of God's names. According to a legend on the Book of Numbers (Num. 6:24), peace is one of the names of God. Peace is immanent in God, or in God's ontology, and has enormous universal significance. God grants worthy individuals a "covenant of peace” as a reward, a token of God's appreciation of an individual's commendable actions.

In the book of Numbers, Pinhas is awarded God's covenant of peace (Num. 25:12-13). God treats Pinhas as a perfect individual whose exemplary conduct during a crisis is described in book of Numbers (Num. 25:6-8). Zimri ben Salu, president of the Tribe of Shimon, had intimate relations with the Midianite woman openly, and his actions became known to Moshe and the entire nation. Everyone was distraught and no one knew what to do. Pinhas was the first to regain his composure and put an end to the disgrace by killing them both. On the face of it, this is an absurd situation, in which Pinhas killed two possibly innocent individuals who were not convicted of a crime by any court, yet he is rewarded with a covenant of peace. The story, however, should be examined from a biblical perspective: Zimri's actions were a blatant public expression of rebellion and protest against Moses, the God-appointed leader, and as such, were considered as a sin in the eyes of God. When Zimri's rebellious acts began, the nation was smitten with a plague that killed 24,000 individuals. Pinhas understood that if the sin was not stopped immediately, the plague would kill off the entire nation. In fact, after he killed Zimri, the plague stopped.

As a result, God rewarded Pinhas for his actions with a "covenant of peace": God granted Pinhasand his offspring special priestly status ("everlasting covenant of priesthood”) (Num. 25:12-13), which is the supreme status among the people of Israel.

Yitzhaki, who lived in France in the 11th century, considered the most lucid Biblical commentator, interprets the biblical phrase "covenant of peace" as a relationship of amity between God and man. Yitzhaki uses the simile of a "...as a man who returns a favor" (Yitzhaki, 1960, Num. 25:12) to illustrate the relationship between God in the story of Pinhas: Pinhas's actions benefited God, and God rewarded Pinhas for his actions by benefiting Pinhas. According to Yitzhaki (1960), the relationship between man and God is reciprocal, and a man's actions can be rewarded in many ways, including a covenant of peace, as in the case of Pinhas.

\section{The Blessing of Peace}

God's blessing is called "peace”. The majority of anonymous Sages concluded this from Psalms (Ps. 29:11): “The LORD will bless his people with peace” (Megila 18a). Peace is so important to God, and so significant an element in God's attitude to man, that the word peace is used on a daily basis when individuals meet and greet each other, according to Jewish tradition.

God greets his nation with peace every day through a special blessing conveyed through the nation's supreme status holders, the priests. The priests greet the nation in morning prayers, whose main message is peace, as we learn: "The LORD lift up His countenance on you, and give you peace" (Num. 6:26). As we see here, the 
blessing that God bestows is the blessing of peace.

Another Biblical commentator, R. Avraham ibn Ezra, who lived in Spain in the 11th and 12th centuries, typically bases his interpretations on the specific linguistic character of biblical verses and oral traditions. He interprets this greeting as "no harm shall come to you, not from a stone or a wild beast, or an enemy" (ibn Ezra, 1960, Num. 6:26). According to ibn Ezra, peace is the absence of harm or damage, a state of tranquility that surrounds the individual on all sides, and as a result of which man attains perfection, with no enemies; man enjoys physical safety in daily life.

\section{Individual "Peace"-Personal Safety and Well-Being}

Genesis (Gen. 28:21) offers an account of Jacob’s vow during his journey from Be'er Sheva to Haran. Jacob, the third of the three forefathers of the Hebrew nation, asks God to watch over him as he traveled, to provide him with food to eat and clothes to wear, and to ensure that he returns "safely to his father's house". Legends, add interpretive details to Jacob's request as livelihood (Bereshit Rabbah 69:6), avoidance of bloodshed (Bereshit Rabbah 70:4), wholeness of the body (Yalkut Shim'oni 22:908), and absence of illness (Seforno, 1960, Gen. 28:21).These legends, which mainly rely on early legends sources from the second century AD onward, interpret Jacob's request for peace as specific requests concerning Jacob's personal affairs, the realization of which is considered his own individual peace based on his personal interests: a request for livelihood, a request that he never be compelled to harm others, and a request that he himself not be harmed by disease or by others. These are all existential and commonplace requests that in being realized create peace for the individual, ensuring the concrete existence of an individual-in this case, Jacob.

In contrast, the following legend interprets the verse "I return to my father's house in safety" (Gen. 28:21) as a request for personal peace from a different perspective (Yalkut Shim'oni, Job 22:908). According to this legend, Jacob not request all the other elements noted above but rather asks for peace for himself, that is to live in peace, without inner conflict for himself and for others in general.

Ibn Ezra, mentioned above, also interprets the verse "Now Jacob came safely to the city of Shechem" (Gen. 33:18) as "he comes in peace, so that no event should befall him", or no harm be caused to him by anything (ibn Ezra, Gen. 33:18).

In this condition, he is physically whole, meaning that he was not distracted, injured, or harmed by any adverse event and he is content with himself and his environment. Yitzhaki the commentator noted above, however, rejects such a simplistic explanation for this verse and he interprets "returns safely" from a spiritual perspective as "perfect without sin, so that I should not sin in Laban’s house” (Yitzhaki, 1960, Gen. 33:18). Laban was Jacob's uncle (his mother's brother). Jacob was sent at his father's request, to his mother's family in Aram, to find a woman to marry (Gen. 28:2; 29:10). Rav, an early third century Babylonian sage, expresses a combination of these two approaches, the material and the spiritual. Rav interprets "return in safety" on the basis of another verse that appears later in the story of Jacob: "And Jacob came safely” (Gen. 33:18) and he says, "Whole in body, whole in his money, and whole in his beliefs" (Shabbat 33b). On this verse, Yitzhaki states,

Whole in his body [means] he was cured of his limp; whole in his money [means] he did not lose money despite the monetary value of his gift to his brother Esau; and whole in his belief [means] that he did not forget his teaching while he was in Laban’s house. (Yitzhaki, 1960, Gen. 33:18) 
Yitzhaki's grandson, R. Shmuel ben Meir, who lived in France in the 12th century, uses a stylistic feature and logical argument to reject his grandfather’s interpretation. He stated:

He who interprets this as whole in his money and whole in his belief-is in error because this is not the typical style of the Bible, and in any case, what is the point—for such a small gift as was given to Esau, what was the need to write it in this way? (ben Meir, 1960, Gen. 33:18)

Literally, ben Meir is correct, because it is no typical of the Bible to note whether an individual who granted a gift was reimbursed for the value of the gift he gave, especially in the specific case at hand, in which Jacob gave a gift to his brother Esau in order to appease him and prevent him from harming him or his family. Although the gift included a large number of animals and camels, it was considered as a small gift compared to Jacob's immense wealth. Therefore, ben Meir argues that Yitzhaki's explanation is not typical of the Bible, that is, the Bible would not typically note that Jacob recovered the value of the gift that he awarded his brother, especially in view of the fact that the gift was a small one, in relation to Jacob's immense wealth. ben Meir therefore rejects Yitzhaki's explanation and offers the literal explanation of the word "shalem".

Ben Meir believes that the word "Shalem" (Gen. 33:18) signifies the city that Jacob reached, which was Shechem's city of residence. In fact, the root of the dispute among the three commentators mentioned above focuses on whether the word "Shalem" should be treated hermeneutically, as ibn Ezra and Yitzhaki argue, or literally, as ben Meir argues. In other words, these are two opposing perspectives, each with its own justifications.

In view of Jacob's conduct and statements resonate with the Jewish tradition that fosters in each individual the ideal of perfection, and the goal of becoming complete, because the individual is part of the whole. Thus, each person has the individual duty to aspire to wholeness and to attain inner peace with himself as a fundamental, material goal in life. In my opinion, ben Meir's literal approach has greater merit than the interpretive approach, because the literal approach is closer to the realistic meaning of the biblical text, without imposing any interpretations that diverge from the simple meaning of the text.

\section{Peace Among Friends}

Peace among friends is reflected in the Bible in the Book of Leviticus (Lev. 19:18): "You shall love thy neighbor as yourself”. Of this verse, R. Akiva, a sage living in late first century AD Israel, says, "this is a major rule in the Bible” (Sifra, Kedoshim 84).

Ben Maimon, a 12th century Jewish philosopher and decisor in matter of Jewish law (Halakhah), states that this is one of the 613 commandments that observant Jews are obligated to perform: "All persons are commanded to love each person in Israel as they love their own self” (Ben Maimon, 1954a, De'ot 6:3).

The biblical verse calls to love every man, whichever nation he belongs to, as a human being. This also appears in the New Testament: “Thou shalt love thy neighbor as they self” (Matthew 19:19; Mark 12:31; Paul, Romans 13:9).

Still, with regards to members of the Hebrew nation, this verse is also a practical commandment, as Ben Maimon elaborates: "A person should love others just as he loves himself; a person should care for the property of others just as he cares for his own property; a person should aspire to things for his friends, just as he aspires to things for himself” (Ben Maimon, 1954b, Asse 206). This is also true for all other things such as a friends' dignity, his interests, retelling his good deeds, and treating him with affection and respect (Azkari, 1966, p. 9). 
This type of behavior leads to peace between companions in society because it prevents any possibility of improper conduct or infliction of harm (HaLevi, 1960, p. 243). The following story about Shamai and Hillel, two first century sages, and its moral for social relations is a classic example of peace among friends:

A gentile once came to Shammai, and wanted to convert to Judaism. But he insisted on learning the whole Torah while standing on one foot. Shammai rejected him, so he went to Hillel, who taught him: "What you dislike, do not do to your friend. That is the basis of the Torah. The rest is commentary; go and learn!” (Shabbat 31a).

Shammai rejected the gentile's request to convert while standing on one foot because considered the gentile's request a snub that reflected contempt for the Torah (since it is not practically feasible to learn the entire Torah in this manner).

Hillel reduced the entire Torah to the single facet of peace in society: "What you dislike, do not do to your friend" (Shabbat 31a). This short sentence can be recited while standing on one foot, and is based on the biblical verse "Love thy neighbor as yourself" (Lev. 19:18) .

But even more so, every individual is commanded by the majority of the anonymous sages, to live in peace with his friends, and neighbors, and always be first to enquire into their welfare (Avot 15:4). According to Boaz, they must even invoke the name of God in making such enquiries, just as Boaz invoked the name of God when he greeted the laborers in the field: "Just then Boaz arrived from Beth Lehem and greeted the harvesters", "The LORD be with you!" "The LORD bless you! they called back” (Ruth 2:4). R. Yohanan ben Zakkai, a first century sage, is applauded for always being the very first person to greet someone (Berachot 17a).

The significance of peace among friends is reflected in Judaism's attitude to the Day of Atonement, the holiest day of the year according to Jewish tradition, on which Jews pray for atonement for the sins they committed against God. Individuals must ask forgiveness directly from those they have sinned against (Yoma 85b).

The attainment of peace therefore requires not only the individual refraining from fighting, but also individuals proactively working toward the attainment of peace, through actions that include compromise or concessions. Furthermore, the absence of peace between individuals is an intolerable situation which might lead to a collective punishment by God, which is what occurred to the 24,000 pupils of R. Akiva, who died because they did not treat each other with respect (Yevamot 62b). According to this story, peace among friends is difficult to attain. When an individual is compelled to make peace with his friend, the effort takes a huge toll in terms of the personal resources required to overcome his own sense of pride. Jewish tradition acknowledged this challenge, and strongly emphasized and encouraged peace among friends.

\section{Biblical Men of Peace: Moses and Aaron}

Several figures in the Pentateuch were known as men of peace, including Moshe and his brother Aaron. The Book of Numbers (Num. 16:1-35) recounts the story of Moses' dispute between Korah, who was Moses' cousin, and his entourage. Korah challenged Moses' leadership, because he was angered by the fact that he did not receive an official appointment that fit what he believed was his high status, being an important person who was closely related to Moses' family. He therefore accuses both Moses and his brother Aaron of being inappropriately patronizing or condescending. Moses is shocked by the accusation and his initial reaction is to literally prostrate himself on the ground (Num.16:4). But, in contrast to what could be expected of an ordinary person, Moses does 
not respond. The absence of any verbal response, in combination with his physical reaction, symbolize Moses' attempt to avoid an altercation with Korah and his desire to achieve a peaceful resolution of the matter. The nation's leader is willing to humiliate himself and personally go to Korah to settle the matter peacefully, rather than use his authority to put Korach in his place. Moses tries to convince Korah that God chose him as the leader, and tries to convince Korah to take back his accusations, otherwise he will be punished. Yitzhaki, the commentator mentioned earlier, interprets Moses' actions as implying that disputes should not be prolonged (Yitzhaki, 1960, Num. 16:12): Moses made a personal effort to persuade Korah and his company to make peace with him .There are no grounds for Korah's accusations, and Moses emphasizes that his leadership and his actions comply with God's orders and instructions. Moses is a theocratic leader and he proves this to Korah through a test: God must choose which is correct, and God chooses Moses (Num. 16:5-7).

Aaron is described as a man of peace. We learn this from the account of his death, especially when it is compared to the biblical story of Moses' death. When Aaron dies, it is written "When all the congregation saw that Aaron had died, all the house of Israel wept for Aaron thirty days” (Num. 20:29), while when Moses dies, the verse says, "So the sons of Israel wept for Moses in the plains of Moab thirty days" (Deut. 34:8). Although the period of mourning for both leaders was identical, the participants were not the same. The entire house of Israel mourned Aaron, with an emphasis on the terms "house", yet for Moses, the mourners were "the sons of Israel" with no reference to the word "house" (Kallah 3). Yitzhaki views this difference as a significant one, and interprets the phrase "house of Israel" to include "the men and the women, because Aaron advocated peace and imposed love between combatants and between man and his wife” (Yitzhaki, 1960, Deut. 34:8). By contrast, women did not mourn for Moses.

Aaron's method of instilling peace between two people in an argument was to speak to each party separately and say that the other party was very sorry. When the parties next met, they reconciled (Kallah 3; Yalkut Shim'oni, Malachi 2:588). Aaron employed a similar method in reconciling spouses. He would turn to the husband and say, "I doubt that you could find another woman like her", and convince the husband to reconcile with his wife.

The following summarizes Aaron's characterization as a man of peace: Hillel, the first century sage, also described Aaron as a person who was "loving peace, and pursuing peace; loving mankind, and bringing them nigh to the Torah" [The written Law of the Jewish, the Pentateuch] (Avot 1:13).

\section{Domestic Harmony}

Peace is a fundamental element of the family. Judaism emphasizes the need for harmony and cooperation between the partners in order to build a joint home on a harmonious foundation. In the Bible, the significance of harmonious domestic relations is reflected in the ritual relating to the portion on unfaithful wives (Num. 5:11-31).

The Sotah [In Hebrew] is a woman whose husband suspects of being unfaithful, although he has no proof. During the time of the First Temple (10th century BC to 586 BC) and the Second Temple (516 BC-70 AD) in Jerusalem, the priests would test the truth of the woman's claim that she was faithful by giving her holy water from the Temple sink in a cup, into which a crumb-size piece of the text of portion Sotah was crumbled (Num. 5:23). "The priest shall then write these curses on a scroll, and he shall wash them off into the water of bitterness and the name of God was crushed" (Shabbat 116a).

Erasing the name of God from a scroll is strictly forbidden, according to the explanation of Yitzhaki to the 
verse: "You shall not act like this toward the LORD your God" (Yitzhaki, 1960, Deut. 12:4). Still, God allowed his name to be obliterated by this water (Sifrei, Num. 17; Sukkah 53b) to test whether the woman was telling the truth and to facilitate reconciliation between husband and wife (Yitzhaki, Sukkah 53b, s.v.: 'La'assot'). The purpose of this test was to prove whether the woman was innocent or whether she was unfaithful to her husband with another man. The test was conducted only when the husband had no proof of his suspicions and when his wife did not admit her transgression. According to the commentators, God would determine the women's guilt and the outcome of the test (Num. 5:11-31).

When the wife insisted on her innocence, there were two options. If the water test proved that she had cheated on her husband, her husband would divorce her without being required to pay her the amount stated in their Ketubah, their prenuptial agreement. If the wife was telling the truth, they would continue to live in peace.

Herr argues that the use of this test changed over time, and from a test applied to unfaithful women to prove their infidelity, it became a test applied to innocent women to prove their innocence (Herr, 1997, pp. 26-27). The water test was designed to convince the husband of his wife's innocence, lest he continue to live in doubt and suspicion, a situation that could create incessant tension and mistrust in their marriage. Thus we learn that "peace between husband and wife" implies normal, harmonious relations. The Bible contains no instructions to perform such a ceremony in the event that a wife suspects her husband of infidelity.

As early as the first century, R. Yohanan ben Zakkai, a first century sage who lived in the Land of Israel, suspended the use of this test. Apparently adultery by both sexes was more common in his era: He claimed that the water test could prove the wife's unfaithfulness only if the husband was free of $\sin$ (Sotah 47a-b). However, the test may have been suspended because the sages were uncomfortable with the fact that the test was not being used for its original purpose (there were attempts to use the test for women who were unable to conceive) (Sifrei, Nasso 19; Berachot 31b; Sotah 26a).

God attributed such great significance to domestic harmony between husband and wife that God exempted women from the obligation to perform the positive, calendar-dependent, commandments (Kiddushin 1:7) such as prayers, the study of the Bible, or using Tefillin (phylacteries) (Kiddushin 34a). The rationale was to facilitate domestic harmony by allowing the wife to perform all her many domestic duties, which she might otherwise neglect had she been obligated to follow these commandments (HaLevi, 1960, p. 5).

We stress, this does not imply that women are domestic servants. Rather, the term "domestic harmony" represents a coordinated division of labor between the spouses, without which harmony is unattainable. The understanding and agreement to conclude such a division of labor does not detract from the status of any partner, but rather enhances peace and harmony in the family nucleus.

\section{Peace Between Israel and the Nations}

Judaism views peace as the normative relations between Israel and other nations. Not only during times of peace but even, and perhaps most importantly, during war, there is an obligation to initiate a call for peace with all nations and avoid warfare. As the Bibles says, "When you approach a city to fight against it, you shall offer it terms of peace... However, if it does not make peace with you, but makes war against you, then you shall besiege it” (Deut. 20:10-12). Even if the city does not make peace, the nation of Israel is obligated first to make a siege against it in order to win and only then conquer the city (Schwartz, 1997, pp. 16-17). This is the reason that R. 
Yossi the Galilean, a sage who lived in the Galilee in the late first century AD, praises peace and says that peace is great: In time of war, nothing should be initiated but peace (Derech Eretz Zuta, Chapter HaShalom).

Moses chose to follow the instruction on international relations (Deut. 20:10-12) and refused to follow God's orders to battle against Sihon (Num. 21:21) the Amorite kind, without first offering peace. Instead, Moses sent messengers to Sihon to offer him terms of peace. Ultimately, God agreed with Moses (Deut. 2:24-32; Compare Num. 21:21-24). Therefore, Moses cautions the people of Israel and tells them always to offer terms of peace to the enemy (Tanhuma, Shoftim19) before going to war against any city or nation (Yalkut Shom'oni, Num. 21:764), as natural law (Ius naturale, the laws common to all beings, based on a rationale that can be inferred from nature, which represents God's wisdom) requires (Herr, 1997, p. 34). If possible, war should be avoided entirely, just as Moses did with the Edomites, by sending the messengers to the King of Edom requesting a right of passage through his kingdom. The Edomites refused to grant this request, and instead declared war against Israel. The Israelites, however, circumvented Edom in order to avoid a war (Num. 20:14-21).

Joshua, Moses' successor, behaved in a similar manner by addressing a letter of peace to each city in Israel before going to war against it. The people of Hiwi and Giv'on made peace with Israel, while 31 other kings preferred war and were vanquished (yShevi'it 6:1; Devarim Rabbah 5:4; Bar Nachman, 1960, Deut. 20:10).

We also see that the wise woman from Avel Beth-Ma'acah (Sam. 2, 20:15-23) reproaches Joab, commander of David's army, for his attempt to destroy the city's walls without first offering peace. Then she spoke, saying, "They were wont to speak in old time, saying: They shall surely ask counsel at Abel; and so they ended the matter" (Sam. 2, 20:18). By doing so, she reminded him of the words of the Bible first to offer terms of peace before waging war. Joab admits his mistake: "Far be it from me that I should swallow up or destroy!” (Sam. 2, 20:20).

Ben Maimon firmly states that the nation of Israel should call for peace before initiating a war. God commands that when the people of Israel come to wage war against a city, they must first ask the city's inhabitants for peace. That is, they are obligated to ask them to make peace with Israel before any war is initiated (Ben Maimon, 1954b, Lo Ta'asse 56). Ben Maimon elaborates on this commandment and applies it to all individuals. Unequivocally he states that no war should be waged without first calling to the enemy for peace (Ben Maimon, 1954a, Melechim 6:1).

Ben Maimon' approach leads naturally to the principle of universal peace among nations. Peace is a supreme value and one of the three foundations of the world (Avot 1:17). Peace is the means through which Israel is blessed in its relations with other nations (Uktzin 3:12), and peace is the model that describes ideal international relations that make a significant contribution to world peace.

In summary, all Jewish individuals, and the Jewish nation as a whole, are obligated to strive toward peace. Individuals should strive to achieve inner peace, and peaceful relations with others in their environment, including their spouses, neighbors, and acquaintances. This universal rule should also be applied vis a vis all nations at all times, including our time, such as with Israel's contemporary peace efforts.

\section{Conclusion}

The concept of peace in the pentateuch has three essential elements: First is the lexical meaning of the word "peace" which is a description of a condition— tranquility, serenity, and quiet. The second meaning stems from 
the linguistic inflections of the Hebrew root of the word: "Shalom" and denotes completion, perfection, and reward. The third meaning of peace is harmony.

The concept of peace in early Jewish sources defined on three levels: The first level encompasses the relationship of peace to God and man and vice versa including the blessing of peace from God to man. Next, is peace as a condition of an individual's state and an individual's relationships with others, including relationships with their spouses and their environment. Finally, the concepts of peace and war between nations, and the potential conflict between peace and truth.

Today, all streams within the Jewish tradition believe in the concept of peace established on the pentateuch although each stream supports a concept of peace that has different limitations or reservations.

\section{References}

Abarbanel, D. Y. (2013). Perush LeMassechet Avot (Commentary to Avot). Israel: Ashkelon, O. Golan edition. Azkari, E. (1966). Sefer Haredim (The book of tremble). Israel: Jerusalem.

Bar Nachman, M. (1960). Perush LaTorah (Commentary to Pentateuch). Israel: Jerusalem, Hassid \& Sinai edition.

Ben Maimon, M. (1954a). HaYad HaHazakah (Maimonides’ Deuteronomy). Israel: Jerusalem.

Ben Maimon, M. (1954b). Sefer HaMitzvot (The book of commandments). Israel: Jerusalem.

Ben Meir, S. (1960). Perush LaTorah (Commentary to Pentateuch). Israel: Jerusalem, Hassid \& Sinai edition.

HaLevi, A. (1960). Sefer HaHinuch (The book of education) (4th ed.). Israel: Jerusalem.

Herr, M. D. (1997). Peace in the philosophy of the sages. In B. J. Schwartz \& M. D. Herr (Eds.), Peace in the Jewish heritage (pp. 2-39). Israel: Jerusalem.

Ibn Ezra, A. (1960). Perush LaTorah (Commentary to Pentateuch). Israel: Jerusalem, Hassid \& Sinai edition.

Schwartz, B. J. (1997). Peace in Israel and the nations-The biblical vision. In B. J. Schwartz \& M. D. Herr (Eds.), Peace in the Jewish heritage (pp. 11-22). Israel: Jerusalem.

Seforno, O. (1960). Perush LaTorah (Commentary to Pentateuch). Israel: Jerusalem, Hassid \& Sinai edition.

Yitzhaki, S. (1960). Perush LaTorah (Commentary to Pentateuch). Israel: Jerusalem, Hassid \& Sinai edition. 